\title{
Diatom diversity and water quality of a suburban stream: a case study of the Rzeszów city in SE Poland
}

\author{
Teresa Noga ${ }^{1 *}$, Jadwiga Stanek-Tarkowska ${ }^{2}$, Urszula Kloc ${ }^{1}$, Natalia \\ Kochman-Kędziora ${ }^{3}$, Mateusz Rybak ${ }^{1}$, Łukasz Peszek $^{3}$ \& Anita Pajączek ${ }^{2}$
}

\author{
${ }^{1}$ Department of Biological Foundations of Agriculture and Environmental Education, Faculty of Biology and Agriculture, University of \\ Rzeszów, Zelwerowicza 8B, 35-601 Rzeszów, Poland \\ ${ }^{2}$ Department of Soil Studies, Environmental Chemistry and Hydrology, Faculty of Biology and Agriculture, University of Rzeszów, Zelwe- \\ rowicza 8B, 35-601 Rzeszów, Poland \\ ${ }^{3}$ Department of Agroecology, Faculty of Biology and Agriculture, University of Rzeszów, Zelwerowicza 8B, 35-601 Rzeszów, Poland \\ *corresponding author (e-mail: teresa.noga@interia.pl)
}

\begin{abstract}
The aim of this work was to investigate the diversity of diatom assemblages developed in the Przyrwa stream, to assess water quality based on benthic diatoms and to make an attempt at the identification of physicochemical factors having the greatest impact on the differentiation of diatom assemblages. Studies were conducted in 2011-2012 on the Przyrwa stream, a left-side tributary of the Wisłok River flowing through the city of Rzeszów and with its spring section located on the borders of the city. A total of 259 diatom taxa were identified in the Przyrwa stream during three studied seasons. At all investigated sites, the most abundant population consisted of Ulnaria ulna (Nitzsch) Compère, Cocconeis pediculus Ehrenb., Achnanthidium minutissimum (Kütz.) Czarnecki var. minutissimum, Navicula gregaria Donkin, Planothidium frequentissimum (Lange-Bert.) Lange-Bert., P. lanceolatum (Brébisson) Lange-Bert., Navicula lanceolata (C. Agardh) Ehrenb., Amphora pediculus (Kütz.) Grunow, Eolimna minima, (Grunow) Lange-Bert., Melosira varians C. Agardh and Cyclotella meneghiniana Kütz. Based on IPS (Specific Pollution Sensitivity Index) and GDI (Generic Diatom Index) indices, the ecological status of the Przyrwa stream was assessed as moderate to poor (mostly III-IV class of water quality), while the TDI (Trophic Diatom Index) index indicated a poor to bad ecological status (mainly IV-V class of water quality).
\end{abstract}

Key words: diatom indices IPS, GDI, TDI, species richness, water quality, RDA, Rzeszów City

\section{Introduction}

Diatoms are producers of organic matter in water and, as such, are the basis of the food chain in seas, oceans and inland waters. Due to a high content of proteins and fat, they provide high-energy food for invertebrates. Diatoms take part in the purification of polluted waters through water oxygenation (photosynthesis), absorption of heavy metal ions (nickel, lead, zinc and titanium), consumption of nutrients, and excretion of compounds that function as antibiotics, etc. (Round 1962). They are characterized by a great diversity of adaptation to ecological conditions. They live in natural waters, artificial reservoirs, in clean and polluted waters and even in sewers in which there are no plants or animals. They are found even in deserts where fog often occurs. The presence of diatoms in such diverse environments is made possible by a large adaptability to environmental factors and because they are able to develop on nearly every kind of substrate. Diatom assemblages are characteristic for each of these habitats (Krammer \& Lange-Bertalot 1986; Rakowska 2001).

Diatoms, as excellent bioindicators, are commonly used in Europe to assess the ecological status of surface waters (Whitton et al. 1991; Lecointe et al. 1993; Prygiel \& Coste 1993; Kelly \& Whitton 1995; Whitton \& Rott 1996; Prygiel et al. 1999; Prygiel 2002; Kelly 2003, 2013; Kelly et al. 2008; Bennion et al. 2014). In Poland, diatoms are used as indicators of environmental conditions and their changes, for studying present and past (paleoecological) ecological status of various 
ecosystems and in environmental monitoring (Gołdyn 1989; Kwandrans et al. 1998, 1999; Kwandrans 2000, 2002; Rakowska 2001; Bogaczewicz-Adamczak \& Dziengo 2003; Gołdyn \& Szelag-Wasielewska 2004; Szelag-Wasielewska 2004; Żelazowski et al. 2004; Dumnicka et al. 2006; Szczepocka \& Szulc 2009; Messyasz et al. 2010, 2014; Rakowska \& Szczepocka 2011; Witak 2013). In the assessment of water quality, specific kinds of software (such as Omndidia) are also used, containing indicative values and degrees of sensitivity of individual diatom taxa (Lecointe et al. 1993).

Research on the diversity of diatoms growing mainly in flowing waters was conducted in the Subcarpathian Voivodeship regularly since 2007 (Noga \& Siry 2010; Tambor \& Noga 2011; Noga 2012; Bernat \& Noga 2012; Pajączek et al. 2012; Noga et al. 2013a, 2014a, 2014b, 2015; Peszek et al. 2015). Similar studies focusing on the diversity of diatoms, using their indicative roles, were conducted within boundaries of the City of Rzeszów (Noga et al. 2012, 2013b; Kocielska-Streb et al. 2014).

The research in this paper comprised the entire length of the Przyrwa stream (from the spring to outlet into the
Wisłok River). Preliminary results of this research were presented in a paper dealing with rare and endangered diatom species of Rzeszów (Noga et al. 2012).

The aim of the study was to investigate the diversity of diatom assemblages developing along the Przyrwa stream, to assess water quality based on benthic diatoms, and to identify the physicochemical factors exerting the greatest impact on the differentiation of diatom assemblages.

\section{Study area}

Rzeszów is located in the south-eastern part of Poland, on the northern border of the Subcarpathian Voivodeship and the Outer Western Carpathian mountain range. The central part of the city lies within the Rzeszowskie Foothills (Fig. 1), but the northern and north-eastern areas of the city are part of the Subcarpathian Proglacial Valley (also called "Rynna Podkarpacka"). Both units belong to the Sandomierska Valley macro-region. The south-eastern part of the city lies within the Outer Western Carpathians and is part of the Dynowskie Foothills mesoregion (Kondracki 2001; Raińczuk 2009).

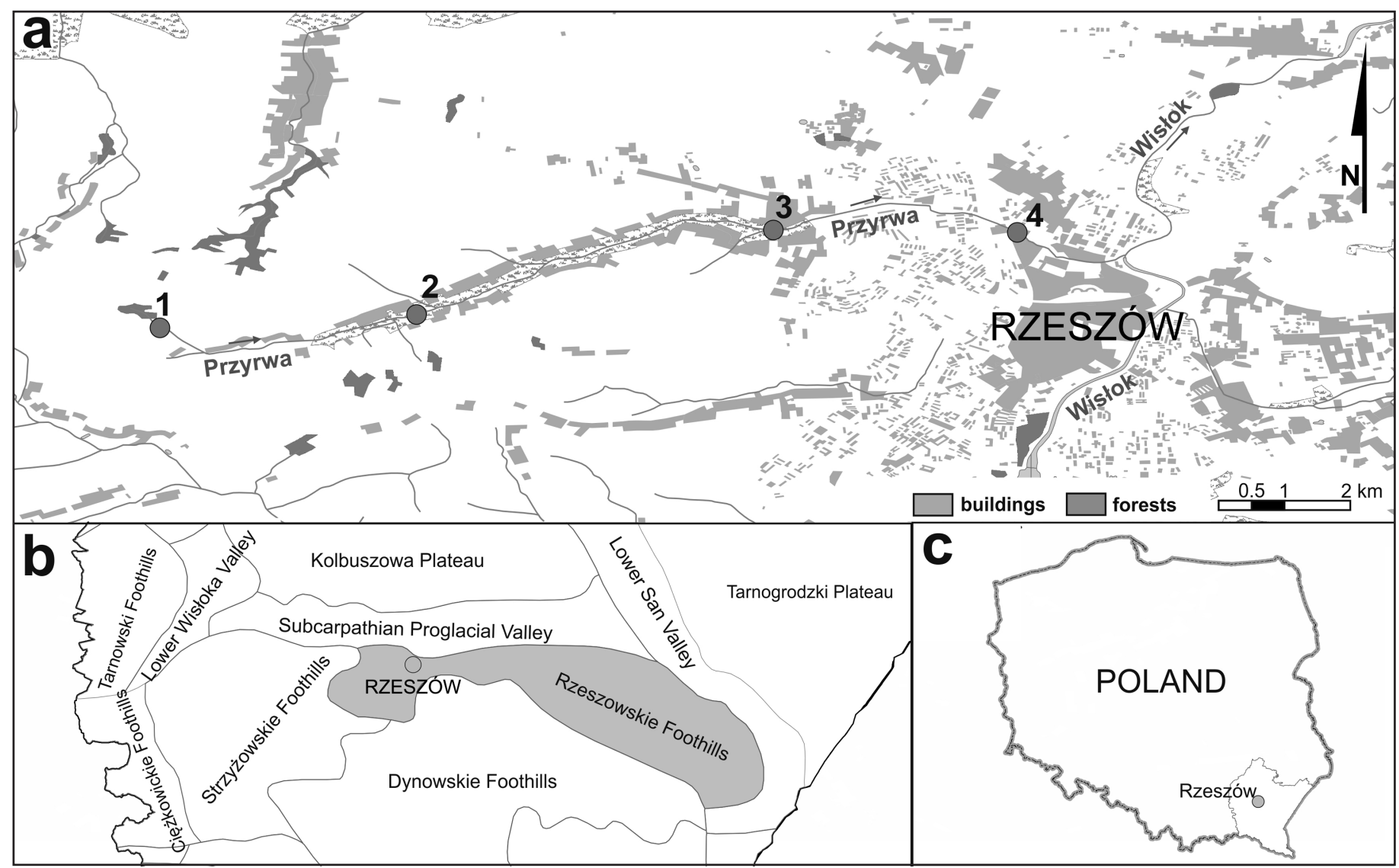

Fig. 1. Study area

Explanations: a - location of sampling sites (1-4) in the Przyrwa stream; b - location of the study area within major geomorphological units, $\mathrm{c}-$ location of the study area in Poland 
The specific location of the city is reflected in the terrain. Areas belonging to the Subcarpathian Proglacial Valley are characterized by the least diversified terrain. The area within the city is flat (201-207 m a.s.1.), gently sloping to the north-east. The Przyrwa stream is a leftbank tributary of the Wisłok River. The upper part of the stream is located in Bzianka (within the municipality of Świlcza), with the middle and the lower sections flowing through the territory of Rzeszów. The Przyrwa stream is a submontane watercourse, with a catchment area of $23.65 \mathrm{~km}^{2}$ and a length of $12.10 \mathrm{~km}$. The spring of the stream is located at the altitude of $258 \mathrm{~m}$ a.s.1., while the estuary sits at $192 \mathrm{~m}$ a.s.l. The Przyrwa stream originates in Bzianka, then flows through Rzeszów (districts: Przybyszówka, Baranówka, the southern part of the Staromieście district) along Dębicka Street and Wyzwolenia Avenue. At the intersection of Siemiński Street and General Maczek Street (the area of the Załęski Bridge), it joins the Wisłok River. It is managed from Lubelska Street trough upstream, up to Route E40, while the section from Lubelska Street to Siemiński Street is not managed. It is a local collector of rainwater. In addition to the existing tributaries, rainwater from collectors is brought from the following areas: Przybyszówka Dworzysko, Przybyszówka near Dębicka Street and Kontorówka. Moreover, rainwater from the upper part of the catchment area (the villages of Bzianka, Bzianka Górna, Kielanówka, Tralówka, Pustki, Przybyszówka Górna, Przybyszówka Dolna and Świdrówka) is introduced into the collector. This significant inflow of rainwater means that during heavy rainfall, the riverbed cannot contain the water and, therefore, overflows (both in the upper part and within the territory of Rzeszów). The Przyrwa stream, like many other Wisłok tributaries, is not currently being analyzed by the Voivodeship Inspectorate for Environmental Protection in Rzeszów. Archived results from the period 1994-1997 indicated that these tributaries had clearly polluted water (Słysz et al. 2004; Basiak 2008; Raińczuk 2009).

\section{Material and methods}

Materials for the studies were collected over two years at four designated sampling sites (1-4) along the Przyrwa stream, including the spring, middle and lower sections of the watercourse (Fig. 1). The first site was designated in the spring section of the Przyrwa stream in the village of Bzianka. It is the only site which remains under minimal influence of anthropogenic pressure (there are meadows and pastures nearby). Site number two was located on the Przybyszówka estate near Dębicka Street and Ciche Wzgórze Street. Site number three was located near Wyzwolenia Avenue on the Baranówka estate in Rzeszów, 50 meters from a housing block on Starzyńskiego Street. At this site, the stream was regulated; both banks and the river channel were paved with hexagonal concrete panels. Torrential rains in consecutive sampling seasons led to a complete destruction of stream regulation, leaving the bed consisting mainly of stones and gravel. Here, down flooding of the surrounding areas by stream waters often takes place. The last site was located in Rzeszów, near the hospital on Rycerska Street.

Materials for the studies were collected in April and September of 2011 and May of 2012. Diatoms were collected, depending on the availability of substrate, from tough substrate - concrete slabs and rocks (algae was scraped using a toothbrush), from silt pipette (suction) and aquatic plants. Samples were collected to $100 \mathrm{ml}$ containers and preserved in a $4 \%$ formalin solution in a laboratory. A total of 20 samples were collected (from one to three samples, depending on substrate availability). For diatom indices calculation, samples collected from rocks were only used.

Water temperature, $\mathrm{pH}$ and conductivity were measured directly in the field. Water for chemical analysis was taken at the same time. Chemical oxygen demand (COD-Cr), biochemical oxygen demand $\left(\mathrm{BOD}_{5}\right)$, total nitrogen, total phosphorus nitrates and ammonia were measured. Chemical analyses were performed using MACHEREY-NAGEL and HACH-LANGE photometry method cuvette tests in the "Wodociagi Dębica" Ltd., Laboratory of Wastewater Treatment. Oxygen content was measured using a field oxygen meter. Ecological status classifications were adopted according to the Decree of the Minister of the Environment from 30 October 2014.

Laboratory processing of diatoms was carried out applying methods used by Kawecka (1980). In order to obtain pure valves of diatoms, part of the obtained material was subjected to maceration in a mixture of sulphuric acid and potassium dichromate at 3:1 proportion and rinsed in a centrifuge (at $2500 \mathrm{rev} \times \mathrm{min}^{-1}$ ). Cleaned diatoms were embedded in Pleurax synthetic resin (refractive index 1.75).

Diatoms were identified and counted under a Nikon ECLIPSE 80i light microscope under 1000× magnification according to Krammer \& Lange-Bertalot (1986, 1988, 1991a, 1991b), Krammer (2000, 2002, 2003), Lange-Bertalot (1993, 2001), Reichard (1999), Werum \& Lange-Bertalot (2004) and Hofmann et al. (2011). The number of given species was obtained through calculating specimens in random light microscope view fields until a total number of 400 valves were obtained. Species whose participation in a given community was $5 \%$ or more were considered as numerous.

The analysis of diatom community structure was conducted using OMNIDIA software (version 4.2, database no. 2015a) to determine the ecological status 
Table 1. The range of indices values and corresponding ecological status according to Dumnicka et al. (2006)

\begin{tabular}{cccccl}
\hline Water Quality Class* & Ecological status & IPS & GDI & TDI & Trophic state \\
\hline I & high & $>17$ & $>17$ & $<35$ & oligotrophic \\
II & good & $15-17$ & $14-17$ & $35-50$ & oligo/mesotrophic \\
III & moderate & $12-15$ & $11-14$ & $50-60$ & mesotrophic \\
IV & poor & $8-12$ & $8-11$ & $60-75$ & eutrophic \\
V & bad & $<8$ & $<8$ & $>75$ & hypertrophic \\
\hline
\end{tabular}

Explanation: * - according to the Regulation (2014)

of water. The software contained an ecological and taxonomic database of diatoms and their bioindication values. Water quality of the Przyrwa stream was assessed based on three diatom indices (IPS, GDI, and TDI) and also the \% of PT indicator. These indices were chosen because they are most commonly used and recommended by many authors to assess water quality in Poland, particularly IPS and GDI (Kawecka et al. 1999; Kwandrans et al. 1999; Żelazowski et al. 2004; Dumnicka et al. 2006; Rakowska \& Szczepocka 2011; Szczepocka et al. 2014).

The IPS index (Specific Pollution Sensitivity Index - Coste in CEMAGREF 1982) and GDI index (Generic Diatom Index - Coste \& Ayphassorho 1991) are scaled from 1 to 20 (an increase in the value of the indicator means an increase in water quality). The TDI (Trophic Diatom Index, Kelly \& Whitton 1995) is scaled from 1 to 100 (the higher the value, the higher trophic state of water). The percentage of pollution tolerant taxa (PT) must be taken into account in the interpretation of the TDI index. There is a possibility of organic pollution if the PT values are above $20 \%$. The classification schemes of Dumnicka et al. (2006) were used to evaluate the ecological status (Table 1).

Species diversity in diatom assemblages was determined using the Shannon-Wiener (H') indicator (Krebs 1997):

$\mathrm{H}^{\prime}=\Sigma(\mathrm{ni} / \mathrm{N} \cdot \log \mathrm{ni} / \mathrm{N})$

$\mathrm{N}$ - total number of taxa

ni - number of individual diatoms of the 'i-th' species In this paper, we distinguished categories of risk for individual diatom taxa using the Red List of Algae for Poland (Siemińska et al. 2006): E - endangered, V vulnerable, $\mathrm{R}$ - rare, I - indeterminate.

Table 2. The values of physico-chemical parameters measured in the Przyrwa stream in 2011-2012 and sampling sites characteristic

\begin{tabular}{|c|c|c|c|c|c|c|c|c|c|c|c|c|}
\hline \multirow{2}{*}{$\begin{array}{l}\text { Sampling site } \\
\text { Date }\end{array}$} & \multicolumn{3}{|c|}{1} & \multicolumn{3}{|c|}{2} & \multicolumn{3}{|c|}{3} & \multicolumn{3}{|c|}{4} \\
\hline & $\begin{array}{c}06 . \\
2011\end{array}$ & $\begin{array}{c}09 . \\
2011\end{array}$ & $\begin{array}{c}03 . \\
2012\end{array}$ & $\begin{array}{c}06 . \\
2011\end{array}$ & $\begin{array}{c}09 . \\
2011\end{array}$ & $\begin{array}{c}03 . \\
2012\end{array}$ & $\begin{array}{c}06 . \\
2011\end{array}$ & $\begin{array}{c}09 . \\
2011\end{array}$ & $\begin{array}{c}03 . \\
2012\end{array}$ & $\begin{array}{c}06 . \\
2011\end{array}$ & $\begin{array}{c}09 . \\
2011\end{array}$ & $\begin{array}{c}03 . \\
2012\end{array}$ \\
\hline Depth [m] & \multicolumn{3}{|c|}{$0.1-0.2$} & \multicolumn{3}{|c|}{$0.3-0.5$} & \multicolumn{3}{|c|}{$\sim 0.1$} & \multicolumn{3}{|c|}{$0.3-0.4$} \\
\hline Width [m] & \multicolumn{3}{|c|}{$0.2-0.4$} & \multicolumn{3}{|c|}{$\sim 0.5$} & \multicolumn{3}{|c|}{2.0} & \multicolumn{3}{|c|}{$3.0-4.0$} \\
\hline Insolation & \multicolumn{3}{|c|}{ average } & \multicolumn{3}{|c|}{ high } & \multicolumn{3}{|c|}{ high } & \multicolumn{3}{|c|}{ low } \\
\hline $\begin{array}{l}\text { Type of the } \\
\text { bottom }\end{array}$ & \multicolumn{3}{|c|}{$\begin{array}{l}\text { muddy } \\
\text { sandy }\end{array}$} & \multicolumn{3}{|c|}{$\begin{array}{l}\text { muddy } \\
\text { sandy }\end{array}$} & \multicolumn{3}{|c|}{$\begin{array}{c}\text { concrete plates/stones } \\
\text { lack of silt }\end{array}$} & \multicolumn{3}{|c|}{$\begin{array}{l}\text { pebble and gravel } \\
\text { at the shore silted }\end{array}$} \\
\hline $\begin{array}{l}\text { Temperature } \\
{\left[{ }^{0} \mathrm{C}\right]}\end{array}$ & 17.2 & 14.4 & 5.6 & 17.0 & 15.2 & 5.9 & 17.6 & 16.0 & 6.5 & 16.8 & 15.7 & 5.7 \\
\hline $\mathrm{pH}$ & 8.1 & 8.0 & 7.6 & 8.0 & 7.9 & 7.9 & 8.4 & 8.0 & 7.9 & 7.8 & 7.8 & 8.0 \\
\hline $\begin{array}{l}\text { Conductivity } \\
{[\mu \mathrm{S} / \mathrm{cm}]}\end{array}$ & 570 & 662 & 300 & 667 & 697 & 558 & 736 & 767 & 654 & 840 & 855 & 716 \\
\hline $\begin{array}{l}\mathrm{COD}-\mathrm{Cr} \\
{\left[\mathrm{mgO}_{2} / 1\right]}\end{array}$ & 11 & 11 & 8 & 19 & 15 & 12 & 15 & 13 & 11 & 12 & 12 & 13 \\
\hline $\begin{array}{l}\mathrm{BOD}_{5} \\
{\left[\mathrm{mgO}_{2} / 1\right]}\end{array}$ & 1 & 1 & 1 & 6 & 3 & 4 & 2 & 2 & 3 & 3 & 2 & 3 \\
\hline $\mathrm{N}_{-{ }_{\mathrm{NH}} 4}[\mathrm{mg} / \mathrm{l}]$ & 0.05 & $<0.01$ & 0.12 & 1.7 & 0.44 & 0.68 & $<0.01$ & 0.10 & 0.41 & 0.60 & 0.57 & 0.76 \\
\hline $\mathrm{N}^{-}{ }_{\mathrm{NO} 3}[\mathrm{mg} / \mathrm{l}]$ & 0.9 & 0.9 & 0.7 & 1.7 & 2.7 & 1.5 & 2.1 & 2.2 & 1.6 & 1.8 & 1.9 & 1.6 \\
\hline $\begin{array}{l}\text { Total N } \\
{[\mathrm{mg} / \mathrm{l}]}\end{array}$ & 3 & 1 & 1 & 5 & 4 & 3 & 4 & 3 & 2 & 4 & 3 & 3 \\
\hline Total P [mg/l] & 0.2 & 0.1 & 0.1 & 0.3 & 0.2 & 0.1 & 0.1 & 0.2 & 0.1 & 0.2 & 0.2 & 0.1 \\
\hline
\end{tabular}


In order to determine the influence of environmental factors on diatom species composition, the redundancy analysis (RDA) was used, with centering and standardization by response variables. The RDA method was selected on the basis of the detrended correspondence analysis (DCA), which had a linear character (length of gradient 0.42 ). Statistical calculations and graphical interpretations were performed using Canoco 5.03 software. Data was considered statistically significant if the level of significance was less than 0.05 (Ter Braak \& Šmilauer 2012). Selected chemical parameters were used for analysis (COD, $\mathrm{BOD}_{5}$, nitrates, ammonia).

\section{Results}

Water $\mathrm{pH}$ during the study was alkaline and had similar values (7.6-8.1) at all sampling sites. Water temperature was within the range of 5.7 to $16.6^{\circ} \mathrm{C}$ depending on sampling season. Electrolytic conductivity increased along the course of the stream. The lowest values of conductivity were recorded in early spring of 2012, the highest - in summer at all sampling sites. Chemical water parameters showed a deviation from the standard corresponding to the first quality class only at site two. $\mathrm{BOD}_{5}, \mathrm{~N}^{-\mathrm{NO}_{3}}$ and phosphorus corresponded to the second quality class, while the content of $\mathrm{N}^{-\mathrm{NH}_{4}}$ showed a below good ecological status. Other sampling sites had similar chemical parameter values, which classified them as first class (Table 2).

In all, 259 diatom taxa were recorded in the Przyrwa stream in the three studied seasons (selected diatom taxa are shown in Fig. 2). The most frequent were taxa from the Nitzschia (39), Gomphonema (28) and Navicula (27) genera. The greatest species richness was at site two, where 172 taxa were found. The smallest number of taxa was recorded in the spring section, at site one -147 taxa (see Appendix 1). The highest values in the ShannonWiener ( $\left.H^{\prime}\right)$ species diversity index were recorded in

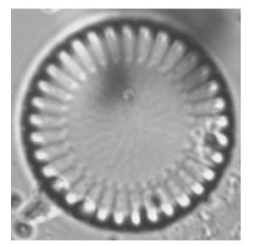

a

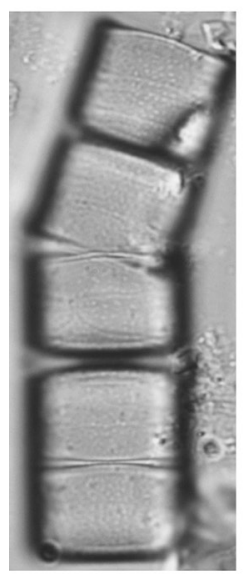

b

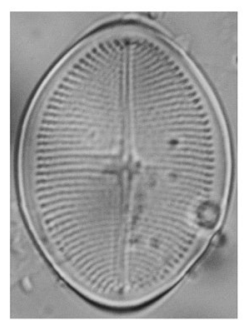

c
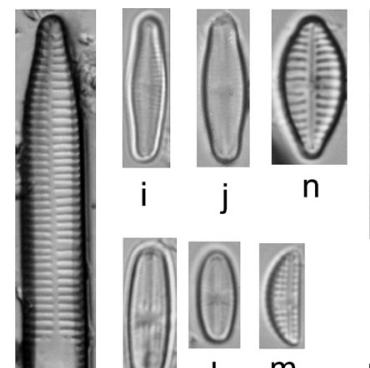

k
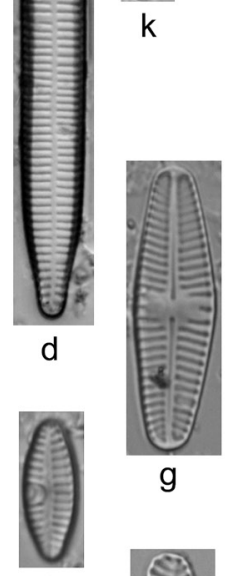

e

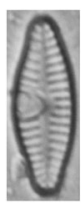

f
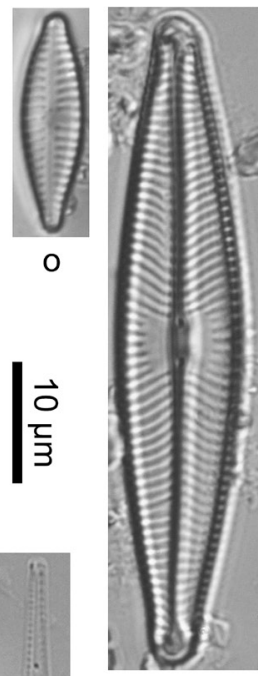

$p$
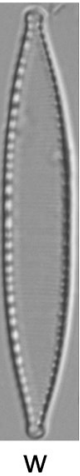
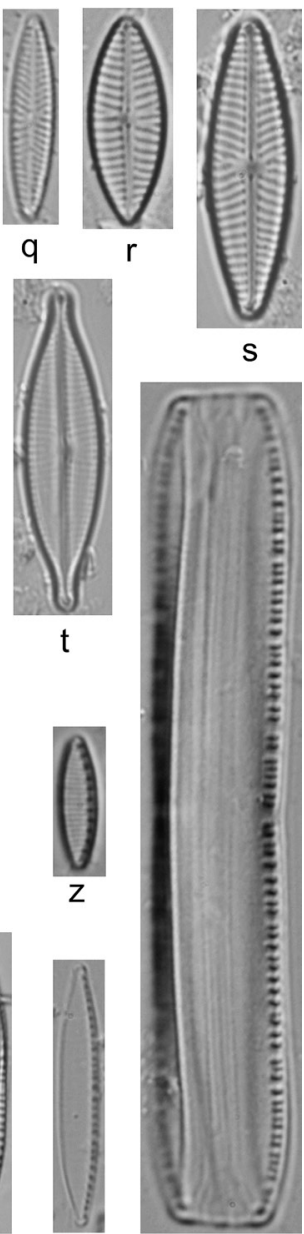

aa

Fig. 2. LM micrographs of dominant diatom taxa recorded in the Przyrwa stream

Explanations: a - Cyclotella meneghiniana, $\mathrm{b}-$ Melosira varians, $\mathrm{c}-$ Cocconeis pediculus, $\mathrm{d}-$ Ulnaria ulna, $\mathrm{e}-\mathrm{f}-$ Planothidium frequentissimum, g-h - P lanceolatum, $\mathrm{i}-\mathrm{j}$ - Achnanthidium minutissimum var. minutissimum, $\mathrm{k}-1$ - Eolimna minima, $\mathrm{m}$ - Amphora pediculus, $\mathrm{n}-\mathrm{o}-$ Gomphonema parvulum var. parvulum, $\mathrm{p}-$ Navicula lanceolata, $\mathrm{q}-N$. tenelloides, $\mathrm{r}-\mathrm{s}-N$. antonii, $\mathrm{t}-N$. gregaria, $\mathrm{u}-\mathrm{v}-$ Nitzschia acicularis, $\mathrm{w}-N$. palea var. palea, $\mathrm{x}-N$. capitellata, $\mathrm{y}-N$. pusilla, $\mathrm{z}-N$. frustulum var. frustulum, aa $-N$. linearis 
Table 3. The IPS, GDI, TDI indices and \%PT values at all sampling sites in the Przyrwa stream in 2011-2012

\begin{tabular}{|c|c|c|c|c|c|}
\hline Date & Site & IPS & GDI & TDI & $\% \mathrm{PT}$ \\
\hline \multirow{4}{*}{06.2011} & 1 & 12.6 & 10.3 & 77.7 & 28.8 \\
\hline & 2 & 12.4 & 11.7 & 73.4 & 44.6 \\
\hline & 3 & 12.5 & 10.8 & 85.6 & 32.0 \\
\hline & 4 & 13.9 & 12.5 & 71.7 & 27.1 \\
\hline \multirow{4}{*}{09.2011} & 1 & 12.7 & 11.0 & 77.2 & 17.6 \\
\hline & 2 & 7.4 & 9.4 & 74.0 & 30.8 \\
\hline & 3 & 11.2 & 11.9 & 81.8 & 19.5 \\
\hline & 4 & 10.6 & 10.6 & 84.4 & 28.6 \\
\hline \multirow{4}{*}{03.2012} & 1 & 13.1 & 11.9 & 77.1 & 14.7 \\
\hline & 2 & 11.4 & 11.4 & 78.5 & 29.0 \\
\hline & 3 & 13.5 & 11.7 & 84.8 & 30.7 \\
\hline & 4 & 12.0 & 10.6 & 84.4 & 36.3 \\
\hline
\end{tabular}

March 2012 at site number two, the lowest - in June 2011 at site number three (Table 2).

Among 259 diatom taxa, 20 taxa were considered as abundant species (i.e. those that accounted for a min. $5 \%$ of relative abundance) (see Appendix 1 - dominant taxa are bolded). The highest relative abundance $(>20 \%)$ were achieved for Ulnaria ulna (Nitzsch) Compère (in summer, at site number one) and Cocconeis pediculus Ehrenb. (in spring, at site number three). The spring section was characterized by numerous development of Planothidium frequentissimum (Lange-Bert.) LangeBert. and P. lanceolatum (Brébisson) Lange-Bert. The most numerously occurring taxa in the middle and lower sections were Navicula gregaria Donkin, N. lanceolata (C. Agardh) Ehrenb., Amphora pediculus (Kütz.) Grunow and Eolimna minima (Grunow) Lange-Bert. (at site number three) and Melosira varians C. Agardh (at site number four). Cyclotella meneghiniana Kütz. (only in summer) and Achnanthidium minutissimum (Kütz.) Czarnecki var. minutissimum (in spring) occurred numerously. At all sites, Achnanthidium minutissimum var. minutissimum and Navicula gregaria were always dominant taxa (Fig. 2).

Water quality investigations were performed using diatom indices calculated employing OMNIDIA software (Lecointe et al. 1993), in order to determine the ecological status of the Przyrwa stream based on the structure of the identified diatom assemblages. IPS and GDI indices showed a better ecological status of the Przyrwa stream (mostly III-IV class) at all sampling sites and seasons compared to the TDI index (indicating mainly IV-V class). The lowest IPS and GDI index values were recorded at site number two in summer, while the highest values were recorded at site number four in spring. Based on diatom indices, the Przyrwa stream was characterized by a moderate and poor water quality. The TDI diatom index value indicated mostly eutrophic and hypertrophic water, the \% of PT indicated the possibility of organic pollutant that could contribute significantly to the eutrophication. The lowest PT values were recorded at site number one in the early spring of $2012(14.7 \%)$, whereas the highest were recorded at site number two in the spring of $2011(44.6 \%)$ - Table 3.

Statistically significant correlations between environmental factors and the structure of diatom assemblages were found $(\mathrm{F}=1.6, \mathrm{p}=0.03)$. RDA analysis explained a fitted variation of $28.5 \%$ in the first axis, $42.2 \%$ - in the second axis, $51.8 \%$ - in the third axis and $59.8 \%$ - in the fourth axis. The environmental factors which were shown to have the most statistically significant influence $(\mathrm{p}<0.05)$ on the differentiation of diatom assemblages were nitrate ions (which explained $25.5 \%$ of variability), electrolytic conductivity $(20.1 \%$ of variability) and $\mathrm{BOD}_{5}$ (16.5\% of variability).

Based on statistical analyses performed using RDA, site number one was distinguished and formed a separate group consisting of all sampling seasons. Separation of this group was associated with the occurrence of Nitzschia linearis (C. Agardh) W. Smith, Navicula antonii Lange-Bert., N. tenelloides Hust., Planothidium frequentissimum and $P$. lanceolatum, which were mostly negatively correlated with the content of the studied chemical indicators (Fig. 3).

In the Przyrwa stream, 23 diatom taxa from the Polish Red List of Algae (Siemińska et al. 2006) were recorded, which constituted $8.9 \%$ of all recorded diatom taxa. Most diatoms were of the R (rare) category - 10 taxa: Achnanthes coarctata (Brébisson) Grunow, Caloneis fontinalis (Grunow) Lange-Bert. \& Reichardt, $C$. lancettula (Schulz-Danzing) Lange-Bert. \& Witkowski, C. molaris (Grunow) Krammer, Fallacia subhamulata (Grunow) D.G. Mann, Luticola acidoclinata LangeBert., Mayamaea excelsa (Krasske) Lange-Bert., Navicula cincta (Ehrenb.) Ralfs, Stauroneis termicola 


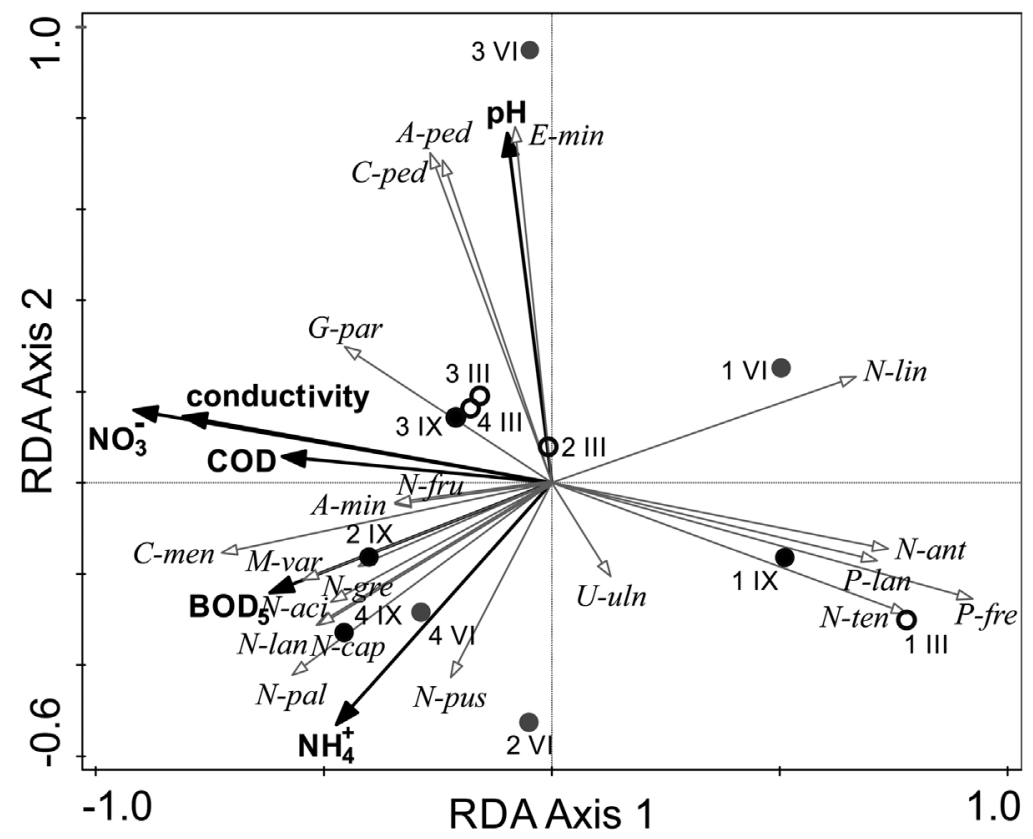

Fig. 3. Diagram of the redundancy analysis (RDA) presenting the relationships between the analyzed diatom assemblages and environment variables (white dots - samples from March, grey dots - samples from June, black dots - samples from September)

Explanations: A-min (Achnanthidium minutissimum var. minutissimum), A-ped (Amphora pediculus), C-ped (Cocconeis pediculus), C-men (Cyclotella meneghiniana), E-min (Eolimna minima), G-par (Gomphonema parvulum var. parvulum), M-var (Melosira varians), N-ant (Navicula antonii), N-gre ( $N$. gregaria), N-lan (N. lanceolata), N-ten (N. tenelloides), N-aci (Nitzschia acicularis), N-cap (N. capitellata), N-fru (N. frustulum var. frustulum), N-lin (N. linearis), $\mathrm{N}$-pal (N. palea var. palea), N-pus (N. pusilla), P-fre (Planothidium frequentissimum), P-lan (P. lanceolatum), U-uln (Ulnaria ulna)

(Petersen) Lund and Surirella brebissonii Krammer \& Lange-Bert. var. brebissonii. Endangered taxa (E) were represented by the following six taxa: Eunotia botuliformis Wild, Nörpel \& Lange-Bert., Fallacia lenzii (Hust.) Lange-Bert., Pinnularia subrupestris Krammer var. subrupestris, P. viridiformis Krammer, Sellaphora pseudopupula (Krasske) Lange-Bert. and Navicula wildii Lange-Bert. In the vulnerable category, (V) five taxa were noted: Gomphonema sarcophagus Gregory, Neidium ampliatum (Ehrenb.) Krammer, Psammothidium lauenburgianum (Hust.) Bukhtiyarova \& Round, Stauroneis gracilis Ehrenb. and S. phoenicenteron (Nitzsch) Ehrenb. Two taxa were found representing category I (indeterminate threat): Eunotia valida Hust. and Ulnaria oxyrhynchus (Kütz.) Aboal. The selected diatom taxa recorded in the Przyrwa stream are presented in Figure 4.

\section{Discussion}

Annual quality assessment and classification of watercourses were based on the analysis of water physicochemical properties. Biological monitoring studies were used sporadically - usually a saprobic system was used, and the index value was determined on the basis of planktonic microorganisms. According to the Water Framework Directive, ecological status is assessed on the basis of biological, physicochemical and hydro-morphological elements. In keeping with the above Directive, the most important elements on which the status of water should be classified are biological elements, while other elements (physicochemical and hydro-morphological) complement them (Panek 2011; Śliwa-Dominiak \& Deptuła 2012).

Monitoring studies were performed on the Przyrwa stream using diatoms to assess water quality by employing three diatom indices from which IPS and GDI are commonly used in bioindication studies based on diatoms in flowing waters. The study conducted showed that the waters of the Przyrwa stream were always of an alkaline character $(\mathrm{pH}>7)$ over the entire length of the watercourse. Most investigated rivers and streams in the Subcarpathian Voivodeship have alkaline or close to neutral reaction, especially in their upper sections (Pajączek et al. 2012; Noga 2012; Noga et al. 2013a, 2013b, 2013c).

The chemical parameters indicated a very good ecological status of the Przyrwa stream - quality class I at sites one, two and three. Elevated values of $\mathrm{BOD}_{5}$, ammonia, nitrates and phosphorus at site two reduced water quality of the stream, indicating a good (II class of water quality) chemical status (Decree of the Minister of the Environment from 30 October 2014). Electrolytic conductivity values were medium or high (300-855 $\mu \mathrm{S} / \mathrm{cm})$. This may have been caused 
by the discharge of sewage from adjacent buildings located in close proximity to the watercourse or may have resulted from agricultural activities (especially in the upper part), runoff from streets and penetration of nutrients from residential areas (in the middle and lower sections). A relatively small and shallow stream favors a greater concentration of nutrients, especially at low water levels, and contributes to the fertility of waters. Comparing the chemical parameters of the Przyrwa stream with other investigated waters in the Subcarpathian Voivodeship, water quality was found similar in Różanka and Matysówka streams and the Mleczka and Morwawa Rivers (Pajączek et al. 2012; Noga et al. 2013b, 2013c).
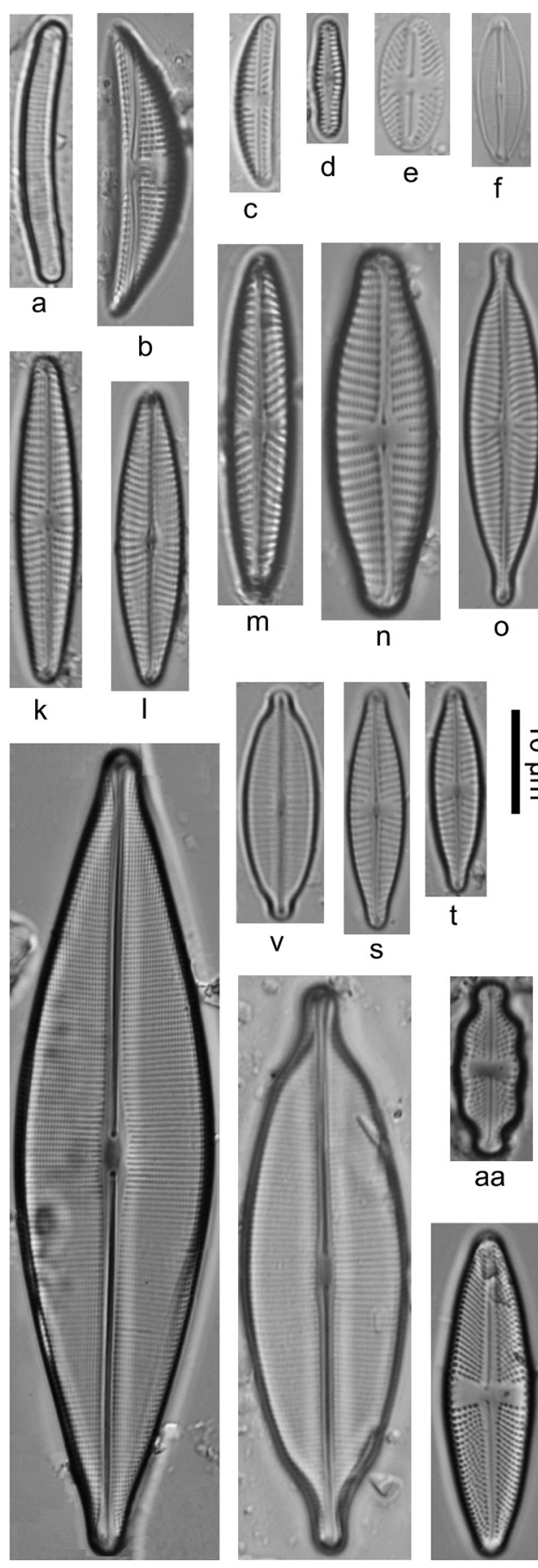

$\mathrm{n}$
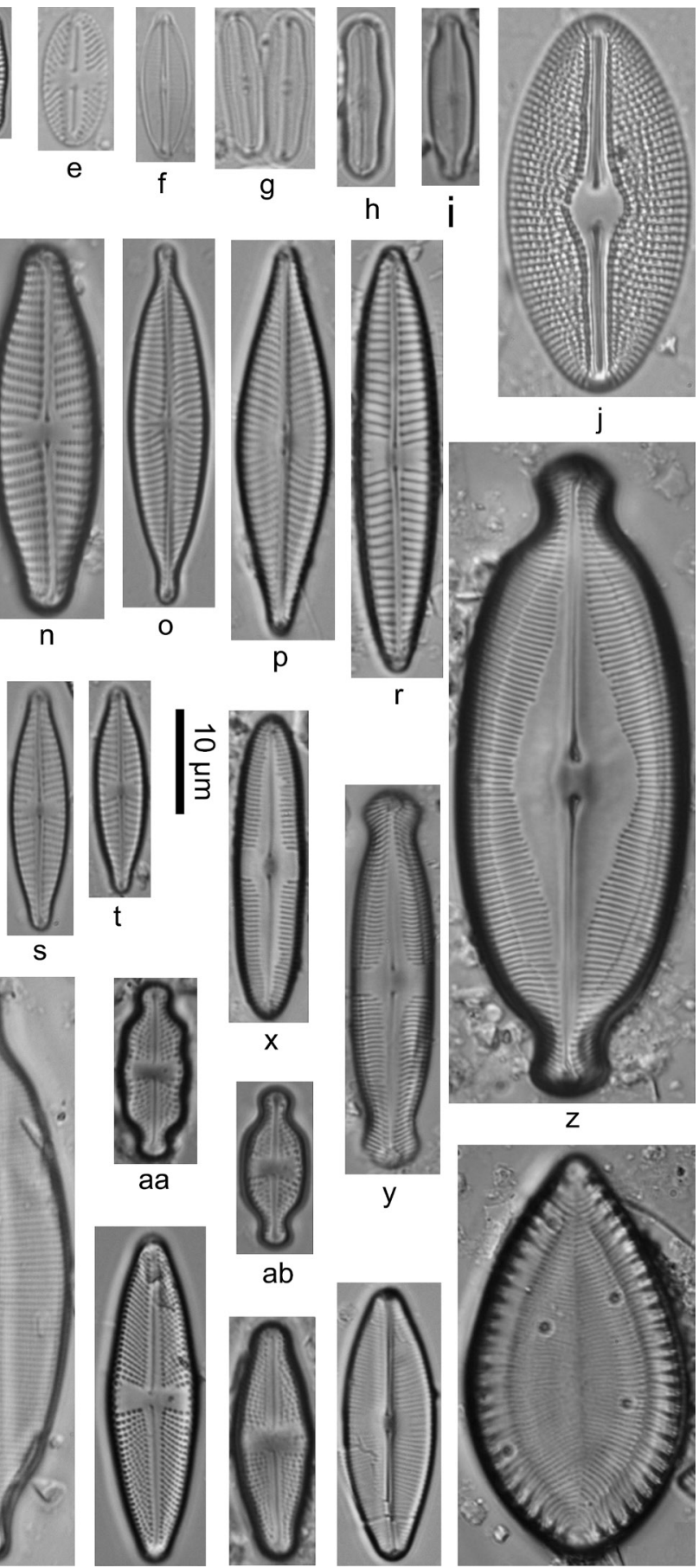

Fig. 4. LM micrographs of selected diatom taxa recorded in the Przyrwa stream

Explanations: a-Eunotia botuliformis, b-Amphora copulata, $\mathrm{c}$-Amphora inariensis, $\mathrm{d}$-Chamaepinnularia muscicola, $\mathrm{e}-$ Mayamaea asellus, $\mathrm{f}-$ Craticula molestiformis, g-h - Fallacia lenzii, $\mathrm{i}$ - Adlafia bryophila, $\mathrm{j}$ - Diploneis krammeri, $\mathrm{k}-$ Navicula libonensis, 1 - N. erifuga, $\mathrm{m}-$ N. cari, $\mathrm{n}-$ N. slesvicensis, $\mathrm{o}-N$. capitatoradiata, $\mathrm{p}-N$. trivialis, $\mathrm{r}-N$. tripunctata, $\mathrm{s}-\mathrm{t}-N$. veneta, $\mathrm{u}-$ Craticula cuspidata, $\mathrm{v}-$ C. accomoda, $\mathrm{w}-C$. ambigua, $\mathrm{x}-$ Caloneis molaris, $\mathrm{y}-$ C. macedonica, $\mathrm{z}-$ C. amphisbaena, aa - Luticola nivalis, ab - L. ventricosa, ac - L. goeppertiana, ad - L. acidoclinata, ae - Sellaphora bacilloides, af - Surirella ovalis 
During the studies conducted in the Przyrwa stream in 2011-2012, the total of 259 diatom taxa was identified. In terms of species richness, the stream does not stand out significantly from other courses in the Subcarpathian Voivodeship - similar numbers of taxa were recorded in the Matysówka (271 taxa) and Różanka streams (202) and in the Morwawa (224) and Mleczka Rivers (277) (Pajączek et al. 2012; Noga et al. 2013b). Many more taxa -401 - were identified in the Wisłok River (Noga 2012) and in the Żołynianka stream (427) (Peszek et al. 2015). The investigated sites in the Przyrwa stream were characterized by a similar number of diatom taxa, and high species diversity indicates that there were favorable conditions for development. A high diatom species richness was also confirmed by Shannon-Wiener $\left(\mathrm{H}^{\prime}\right)$ species diversity index values ranging from 3.83 to 5.91; it reached the highest value at the second site, at which the most diatom taxa were noted. The Przyrwa stream was characterized by the occurrence of 20 abundant taxa. At all sites, Navicula gregaria were dominant. Achnanthidium minutissimum var. minutissimum were dominant taxa at all sites but only in June 2011. The largest populations $(>20 \%)$ consisted of Ulnaria ulna (in summer, the first site) and Cocconeis pediculus (in spring, at the third site).

Achnanthidium minutissimum var. minutissimum is one of the most common diatoms in waters with different hydrological conditions. It prefers waters from oligo- to eutrophic, $\beta$-mesosaprobic (II class). It has a wide spectrum of tolerance in terms of $\mathrm{pH}$ (from 4.3 to 9.2). It occurs most frequently in the upper sections of watercourses, in clean and well oxygenated waters, prefers mountain streams with stony beds and high-speed water flows (Krammer \& Lange-Bertalot 1991b; Van Dam et al. 1994; Hofmann et al. 2011). In the Przyrwa stream, species occurred at all four sampling sites in the spring season in June 2011, reaching $10-20 \%$ in number at site two and 5-10\% of the number at site one. Currently, new species separated from Achnanthidium minutissimum complex are described, but their ecology is still not specified (Novais et al. 2015). However, cells growing in the Przyrwa stream were typical for A. minutissimum var. minutissium. In the Subcarpathian Voivodeship, the taxon occurs in many rivers and streams, often reaching the rank of dominant, especially in upper sections of watercourses (Noga \& Siry 2010; Tambor \& Noga 2011; Noga 2012; Pajączek et al. 2012; Noga et al. 2013a, 2013b, 2013c, 2014a, 2014b, 2015; Peszek et al. 2015).

In the middle and lower reaches of the Przyrwa stream, Navicula gregaria developed numerously (about $20 \%$ of the total in the spring season of 2011). It is a cosmopolitan species in Central Europe, one of the most common diatoms, and has been characterized as meso-halophilous. It occurs in marine habitats, brackish waters up to oligotrophic freshwaters with an average content of electrolytes. Optimum occurrence is at lower temperatures and is tolerant to pollution up to $\alpha$-mesosaprobic (Krammer \& Lange-Bertalot 1986). It is found most often in the lower reaches of rivers, where waters significantly slow down and bring a large amount of sediment. It is one of the most dominant species in most of the rivers and streams in the Subcarpathian Voivodeship, especially in their middle and lower sections (Bernat \& Noga 2012; Noga 2012; Pajączek et al. 2012; Noga et al. 2013a, 2013b, 2013c, 2014a, 2015; Peszek et al. 2015).

Another dominant species in the Przyrwa stream, Cocconeis pediculus, occurred massively in the spring of 2011 at the third site, reaching more than $20 \%$ in number. It is an epiphytic and cosmopolitan diatom, occurring in inland waters with a medium to high content of electrolytes and in coastal salt waters. The species often massively covers other green algae and taller plants submerged in water by wearing a coat in the form of so-called "scum" (Krammer \& Lange-Bertalot 1991b).

Ulnaria ulna occurs in oligo- to polytrophic and oligo-saprobic to $\alpha$-mesosaprobic waters (Hofmann et al. 2011). It is a diatom resistant to and tolerant of saprobic water pollution and its presence in the Przyrwa stream ( $>20 \%$ of the number at site 1 in the summer of 2011) showed the eutrophic character of the stream.

Statistical analysis (using RDA method) showed that in terms of the domination structure, the first site, associated with Navicula antonii, N. tenelloides, Nitzschia linearis, Planothidium frequentissimum and P. lanceolatum, was the most distinguished among the other ones. These species were mostly negatively correlated with the studied chemical parameters. These diatoms have a wide ecological amplitude of occurrence in different types of waters, often alkaline and rich in calcium ( $\mathrm{Na}$ vicula tenelloides, Nitzschia linearis) and, frequently, under conditions of medium to high trophy (Krammer \& Lange-Bertalot 1986, 1988, 1991b; Lange-Bertalot 2001; Hofmann et al. 2011). In the Subcarpathian Voivodeship, they often achieve their highest numbers in the upper reaches of small rivers and streams (Noga \& Siry 2010; Bernat \& Noga 2012; Pajączek et al. 2012; Noga et al. 2013b, 2013c; Peszek et al. 2015).

Comparing diatom indices with chemical parameters, which classify the Przyrwa stream mostly at I and II class of water quality, the obtained index values greatly underestimated the quality of the watercourse, pointing to a moderate, poor or bad ecological status of the stream (III-V class). Chemical analyses characterize the water at the time of measurement, while aquatic organisms are influenced by specific physicochemical conditions resulting from the type and degree of pollution. They allow us to better determine water quality 
through changes in the environment for longer periods of time (Kołodziejczyk et al. 1998).

IPS and GDI indices of general pollution showed better water quality along the entire length of the Przyrwa stream (mostly moderate and poor ecological status - III or IV class) compared with the TDI trophic index, which indicated a poor or bad ecological status of the stream (IV-V class). The values of PT for most studied sites were higher than $20 \%$, which suggests the possibility of organic pollution, especially in the middle and lower reaches of the stream. At the second site in the spring season, the PT was $44.6 \%$, indicating that the factor limiting growth of diatoms need not have been phosphates but other factors like, for example, organic pollution. In the case where the PT index values were lower than $20 \%$, the TDI index could give a reliable indication of the nutrient status of the river (Kelly \& Whitton 1995; Kelly et al. 2001). Only in the upper section, the PT index showed less than $20 \%$. For this reason, IPS and GDI indices seem to work better in the assessment of water quality in Poland.

IPS and GDI indices were previously used to assess the quality of rivers in the southern part of Poland (Kawecka et al. 1999; Kwandrans et al. 1999; Dumnicka et al. 2006). Moreover, IPS and GDI indices were among those proposed for water assessment in the Gulf of Gdansk (Bogaczewicz-Adamczak \& Dziengo 2003). Studies carried out in central Poland showed that the IPS index works best in assessing water quality and can be widely used in Poland to assess saprobic pollution of flowing waters (Szczepocka \& Szulc 2009; Rakowska $\&$ Szczepocka 2011). Its universality results from the fact that it includes the largest number of taxa - about 2500 (Prygiel 2002). During the studies carried out so far, the highest correlation with environmental factors was obtained just using the IPS index (Kawecka et al. 1999; Kwandrans et al. 1999; Bogaczewicz-Adamczak $\&$ Dziengo 2003). Also in Finland and France, the IPS index yielded the best results in the assessment of water quality (Descy \& Coste 1990; Eloranta \& Kwandrans 1996). The analysis of relationships between diatoms indices and abiotic factors showed that IPS is the most adequate index for water quality assessment in many European Union countries (Prygiel \& Coste 1993; Szabó et al. 2004; Gomà et al. 2005; Blanco et al. 2007).

In the Subcarpathian Voivodeship, studies are being conducted using diatom indices, which also confirm that GDI and IPS indices work better than TDI in the assessment of water quality (Noga et al. 2013a, 2013b, 2013c, 2015; Peszek et al. 2015). The trophic index significantly indices worse investigated waters quality, reaching the highest values (bad ecological status), especially in small streams (Noga et al. 2013b, 2013c; Peszek et al. 2015).
In the flora of the Przyrwa stream, 23 diatom taxa from the Polish Red List of Algae were found $-8.9 \%$ of the total of indicated diatoms. The Matysówka stream was characterized by a similar number of taxa from the Red List (25 taxa). That stream flows through the territory of the city of Rzeszów (Noga et al. 2012, 2013b).

Six taxa were noted as endangered (E): Eunotia botuliformis, Fallacia lenzii, Pinnularia subrupestris, P. viridiformis, Sellaphora pseudopupula and Navicula wildii. Most of them occurred in many investigated watercourses within the territory of the Subcarpathian Voivodeship, but often in the form of single cells (Noga \& Siry 2010; Tambor \& Noga 2011, 2012; Bernat \& Noga 2012; Pajączek et al. 2012; Noga et al. 2013b, 2013c, 2014a, 2014b, 2015; Peszek et al. 2015), some, like Eunotia botuliformis or Navicula wildii, occurred very rarely.

Eunotia botuliformis was found in the Przyrwa stream only at the second site, as a single cell. The optimum occurrence of this species was determined in streams with a siliceous bed in the lowlands of northern Germany, where it formed very large populations in places. It occurred in streams and stagnant waters at medium-height mountainous areas and, less frequently, in lowlands. It was found especially in anthropogenically altered, oligotrophic or dystrophic low-electrolyte waters (Hofmann et al. 2011). It occurred very rarely in springs in southern Poland (Wojtal 2013) and the upper part of the San River (Noga et al. 2014b).

Navicula wildii also occurred in the Przyrwa stream, but only in spring sections as a single cell. It develops in less numerous populations, in calcium-rich, oligoto slightly mesotrophic lakes. Optimum occurrence is in alpine and sub-alpine areas, and it is rarely noted in lowlands of northern Germany. It is an indicator of very good water quality (Hofmann et al. 2011). So far, it was very rarely reported in the area of NW Poland (Witkowski et al. 2011).

Among the diatoms indicated in the Przyrwa stream, species very rare to Poland were found. These species do not appear on the Polish Red List of Algae, but have a very interesting ecology, as does Caloneis macedonica. It is a species recorded in the Balkans, Sinai and the lakes of northern Germany (Krammer \& Lange-Bertalot 1986). It was also noted in springs in central Poland (Żelazna-Wieczorek 2011). Within the territory of the Subcarpathian Voivodeship, a single specimen was also found in the Mleczka River (Pajączek et al. 2012). In the Przyrwa stream, the species occurred in the form of single specimens at the second and third sites.

All species that were considered rare or endangered had an average value of indication (indicator value 2). Their ecological range was contained mainly between stenoency (indicator value 3) and euryency (indicator value 1) - according to OMNIDIA 4.2. 
The Przyrwa stream, in the middle and lower sections flowing through urban areas, was transformed anthropogenically. Nevertheless, in the waters of the stream, a number of rare and endangered species from the Polish Red List of Algae were noted. Also, other watercourses flowing through Rzeszów area are characterized by a high species richness and presence of rare and interesting diatoms (Noga et al. 2012, 2013a). Construction of sewage systems in all towns located along the course of the stream could further contribute to the improvement in water quality, which is currently characterized by very high fertility and provides habitats to many eutrophic diatom taxa.

Most chemical parameters showed a very good chemical status of the Przyrwa Stream waters (first class), while the diatom indices showed poorer quality of water (moderate and poor ecological status). Living organisms such as diatoms are influenced by many environmental factors (water chemistry, the nature of the substrate, diversity of habitats, insolation, flow volume, etc.). Therefore, in the anthropogenically transformed stream, they will indicate inferior water quality compared to chemical parameters.

Acknowledgements. We would like to thank Mr. Jacek Gil, MEng, President of the Board of Water Supply Dębica Ltd., for the possibility of chemical analysis in the Laboratory of Wastewater Treatment. We would also like to thank David Duffy for checking of the English language of the manuscript and for his valuable comments.

\section{References}

BASIAK E. 2008. Aktualizacja programu rozwoju kanalizacji deszczowej dla miasta Rzeszowa z uwzględnieniem przyłączonych do Rzeszowa - Załęża, Słociny, Przybyszówki.

Bennion H., Kelly M. G., Juggins S., Yallop M. L., Burgess A., JAMieson J. \& KRoKowski J. 2014. Assessment of ecological status in UK lakes using benthic diatoms. Freshwater Science 33(2): 639-654.

Bernat P. \& Noga T. 2012. Różnorodność zbiorowisk okrzemek potoku Trzcianka. Rocznik Przemyski 47(3): 29-44.

Blanco S., Bécares E., Cauchie H. M., Hoffmann L. \& ECTOR L. 2007. Comparison of biotic indices for water quality diagnosis in the Duero Basin (Spain). Arch. Hydrobiol. Suppl. 16(3-4): 267-286.

Bogaczewicz-Adamczak B. \& Dziengo M. 2003. Rusing benthic diatom communities and diatom indices to assess water pollution in the Pucka Bay (Southern Baltics Sea) littoral zone. Oceanol. Hydrobiol. St. 32(4): 131-157.

Cemagref 1982. Etude des methods biologiques quantitative d'appréciation de la qualité des eaux - Rapport Division Qualité des Eaux Lyon - Agence financiére de Bassin Rhone - Méditerranée - Corse, Pierre-Bénite, $218 \mathrm{pp}$.

Coste M. \& Ayphassorho H. 1991. Étude de la qualité des eaux du Bassin Artois-Picardie a l'aide des communautés de diatomées benthiques (Application des indicesdiatomiques). Raport Cemagref. Bordeaux - Agence de l'Eau Artois-Picardie. Douai, 277 pp.

Descy J. P. \& Coste M. 1990. Utilisation des diatomées benthiques pour l'évaluation de la qualité des eaux courantes. In: CEE Contract B-71-23. Rapport Final. UNECED, FVDP, Namur (Belgium) and CEMAGREF, Bordeaux (France), 64 pp.
Dumnicka E., Jelonek M., Kwadrans J., Wojtal A. \& ŻUrek R. 2006. Ichtiofauna i status ekologiczny wód Wisły, Raby, Dunajca i Wisłoki. 220 pp. Institute of Nature Conservation, Polish Academy of Science, Kraków.

Eloranta P. \& Kwandrans J. 1996. Testing the use of diatoms and macroalgae for river monitoring in Finland. In: B. A. Whitton \& E. Rotт (eds.). Use of algae for monitoring rivers II, 119-124 pp. Institut für Botanik, Universität Innsbruck

GoŁdyn R. 1989. Algae in the seston of the middle section of the River Radunia, its tributaries and dam reservoirs (northern Poland). Fragm. Florist. Geobot. 34(1-2): 201-245.

Goldyn R. \& Szeląg-Wasielewska E. 2004. Changes in the phytoseston of a river-lake system in Drawieński National Park. Oceanol. Hydrob. Studies 33(2): 17-28.

Gomà J., Rimet F., Cambra J., Hoffmann L. \& Ector L. 2005. Diatom communities and water assessment in mountain riverso $f$ the upper Segre basin (La Cerdanya, Oriental Pyrenees). Hydrobiologia 551: 219-225.

Hofmann G., Werum M. \& Lange-Bertalot H. 2011. Diatomeen im Süßwasser - Benthos von Mitteleuropa. Bestimmungsflora Kieselalgen für die ökologische Praxis. Über 700 der häugfisten Arten und ihre Ökologie. 908 pp. A. R. G. Gantner Verlag K. G., Rugell.

KAwECKA B. 1980. Sessile algae in European mountains streams. 1. The ecological characteristics of communities. Acta Hydrobiol. 22: 361-420.

Kawecka B., Kwandrans J. \& Szyjkowski A. 1999. Use of algae for monitoring rivers of Poland - situation and development. In: J. Prygiel, B. A. Whitton \& J. BuKOWSKA (eds.). Use of algae for monitoring rivers III, 57-65 pp. Agence de 1'Eau Artois-Picardie.

Kelly M. G. 2003. Short term dynamics of diatoms in an upland stream and implications for monitoring eutrophication. Environmental Pollution 125: 117-122. 
Kelly M. G. 2013. Data rich, information poor? Phytobenthos assessment and the Water Framework Directive. European Journal of Phycology 48: 437-450. http:// dx.doi.org/10.1080/09670262.2013.852694

Kelly M. G. \& Whitton B. A. 1995. The Trophic Diatom Index: a new index for monitoring eutrophication in rivers. J. Appl. Phycol. 7: 433-444. http://dx.doi. org/10.1007/BF00003802

Kelly M. G., Adams C., Graves A. C., Jamieson J., Krokowski J., Lycett E. B., Murray-Bligh J., Pritchard S. \& WiLkins C. 2001. The Trophic Diatom Index: A User's Manual. Revised Edition, 1-74 pp. Environment Agency, Bristol, BS32 4UD.

Kelly M. G., Juggins S., Guthrie R., Pritchard S., Jamieson J., Rippey B., Hirst H. \& Yallop M. 2008. Assessment of ecological status in U.K. rivers using diatoms. Freshwater Biology 53: 403-422. http://dx.doi. org/10.1111/j.1365-2427.2007.01903.x

Kocielska-Streb M., Pajączek A., Peszek Ł., Kochman N., Noga T. \& Stanek-Tarkowska J. 2014. Okrzemki (Bacillariophyceae) Zalewu Rzeszowskiego. Rocznik Przemyski 50(4): 21-40.

KoŁodZIEJCZYK A., Koperski P. \& KAMiŃSKi M. 1998. Klucz do oznaczania słodkowodnej makrofauny bezkręgowej. Biblioteka monitoringu środowiska, Państwowa Inspekcja Ochrony Środowiska, Warszawa.

Kondracki J. 2001. Geografia regionalna Polski. 441 pp. Wyd. Nauk. PWN, Warszawa.

Krammer K. 2000. The genus Pinnularia. Vol. 1. In: H. Lange-Bertalot (ed.). Diatoms of Europe, 1-703 pp. A. R. G. Gantner Verlag K. G., Königstein-Germany.

Krammer K. 2002. Cymbella. In: H. Lange-Bertalot (ed.). Diatoms of Europe, 3, 584 pp. A. R. G., Gantner Verlag K. G., Rugell.

Krammer K. 2003. Cymbopleura, Delicata, Navicymbula, Gomphocymbellopsis, Afrocymbella. In: H. LANGEBertalot (ed.). Diatoms of Europe, 530 pp. A. R. G., Gantner Verlag K.G., Rugell.

Krammer K. \& Lange-Bertalot H. 1986. Bacillariophyceae. 1. Naviculaceae. In: H. Ettr, J. Gerloff, H. Heyning \& D. Mollenhauer (eds.). Süsswasserflora von Mitteleuropa 2(1): 1-876. G. Fischer Verlag, Stuttgart-New York.

Krammer K. \& Lange-Bertalot H. 1988. Bacillariophyceae. 2. Bacillariaceae, Epithemiaceae, Surirellaceae. In: H. Ettl, J. Gerloff, H. Heyning \& D. Mollenhauer (eds.). Süsswasserflora von Mitteleuropa 2(2): 1-596. G. Fischer Verlag, Stuttgart-New York.

Krammer K. \& Lange-Bertalot H. 1991a. Bacillariophyceae. 3. Centrales, Fragilariaceae, Eunotiaceae. In: H. EtтL, J. Gerloff, H. Heyning \& D. Mollenhauer (eds.). Süsswasserflora von Mitteleuropa 2(3): 1-576. G. Fischer Verlag, Stuttgart-Jena.

Krammer K. \& Lange-Bertalot H. 1991b. Bacillariophyceae. 4. Achnanthaceae, Kritische Ergänzungen zu Navicula (Lineolate) und Gomphonema, Gesamtliteraturverzeichnis. In: H. Ettr, J. Gerloff, H. Heyning \& D. Mollenhauer (eds.). Süsswasserflora von Mitteleuropa 2(4): 1-437. G. Fischer Verlag, Stuttgart-Jena.
KWANDRANS J. 2000. The benthic flora in small forest streams with different water trophy level and $\mathrm{pH}$ status (Pogórze Wielickie Hills, Southern Poland). Acta Hydrobiol. 42(3-4): 241-255.

Krebs CH. J. 1997. Ekologia. 734 pp. PWN, Warszawa.

KwANDRAns J. 2002. Upper Vistula River: Response of aquatic communities on pollution and impoundment. IX. Benthic diatom communities. Pol. J. Ecol. 50(2): 223-236.

Kwandrans J., Eloranta P., Kawecka B. \& Wojtan K. 1998. Use of benthic diatom communities to evaluate water quality in rivers of southern Poland. J. Appl. Phycol. 10: 193-201. http://dx.doi.org/10.1023/A:1008087114256

Kwandrans J., Eloranta P., Kawecka B. \& Wojtan K. 1999. Use of benthic diatom communities to evaluate water quality in rivers of southern Poland. In: J. Prygiel, B. A. Witton \& J. Bukowska (eds.). Use of algae for monitoring rivers III, pp. 154-156. Agence de l'Eau Artois-Picardie.

Lange-Bertalot H. 1993. 83 New taxa and much more than 100 taxonomic clarifications supplementary to Süßwasserflora von Mitteleuropa. Vol. 2/1-4. J. Cramer, Berlin-Stuttgart

Lange-Bertalot H. 2001. Diatoms of the European inland waters and comparable habitats. Navicula sensu stricto, 10 genera separated from Navicula sensu lato, Frustulia. In: H. LAnge-Bertalot (ed.). Diatoms of Europe, 2: 1-526. A. R. G. Gartner Verlag K. G., Vaduz.

Lecointe C., Coste M. \& Prygiel J. 1993. OMnidiA, a software for taxonomy, calculation of diatom indices and inventory management. Hydrobiologia 269/270: 509-513. http://dx.doi.org/10.1007/BF00028048

Messyasz B., Szczuka E., Kaznowski A. \& Burchardt L. 2010. The spatial changes of phytoseston and microbiological parameters in lowland rivers during the summer period. Polish J. Environ. Stud. 1(6): 1269-1277.

Messyasz B., Staniszewski R. \& Jusik S. 2014. Algae assemblages and dominant macrophytes in small lowland rivers of Poland in relation to water quality and hydromorphology. Fresenius Environmental Bulletin 23(2A): 581-588.

Noga T. 2012. Diversity of diatom communities in the Wisłok River (SE Poland). In: K.WoŁowsKi, I. KaCZMARSKA, J. M. Ehrman \& A. Z. Wojtal (eds.). Current advances in algal taxonomy and its applications: phylogenetic, ecological and applied perspective, pp. 109-128. W. Szafer Institute of Botany, Polish Academy of Sciences, Kraków.

NogA T. \& SiRY K. 2010. Różnorodność flory okrzemek w potoku Łubienka (Pogórze Dynowskie, Polska SE). Zeszyty naukowe PTIE i PTG 12: 75-86.

Noga T., Stanek-Tarkowska J., Kocielska-Streb M., Kowalska S., Ligęzka R., Kloc U. \& Peszek Ł. 2012. Endangered and rare species of diatoms in running and standing waters on the territory of Rzeszów and the surrounding area. In: J. Kostecka \& J. KANIUCZAK (eds.). Practical Applications of Environmental Research, pp. 331-340. Rzeszów. 
Noga T., Stanek-Tarkowska, Pajączek A., Peszek Ł. \& Kochman N. 2013a. Ecological characteristics the diatoms of river Wisłok using their role of indicators for assessing water quality. Journal of Ecological Engineering 14(3): 18-27. http://dx.doi.org/10.5604/ 2081139X.1066219

Noga T., Stanek-Tarkowska J., Peszek Ł., Pajączek A. \& KowalsKa S. 2013b. Use of diatoms to assess water quality of anthropogenically modified Matysówka stream. Journal of Ecological Engineering 14(2): 1-11. http://dx.doi.org/10.5604/2081139X. 1043166

Noga T., Stanek-Tarkowska J., Pajączek A., Peszek Ł., Kochman N., WoźniaK K. 2013c. Application of diatoms to assess the quality of the waters of the Baryczka stream, left-side tributary of the River San. Journal of Ecological Engineering 14(2): 8-23. http://dx.doi. org/10.5604/2081139X.1055818

Noga T., Kochman N., Peszek Ł., Stanek-Tarkowska J. \& PAJĄCZEK A. 2014a. Diatoms (Bacillariophyceae) in rivers and streams and on cultivated soils of the Podkarpacie Region in the years 2007-2011. Journal of Ecological Engineering 15(1): 6-25. http://dx.doi. org/ 10.12911/22998993.1084168

Noga T., Stanek-Tarkowska, Pajączek A., Kochman N. \& Peszek Ł. 2014b. Ecological assessment of the San River water quality on the area of the San Valley Landscape Park. Journal of Ecological Engineering 15(4): 12-22. http://dx.doi.org/10.12911/22998993.1125453

Noga T., Stanek-Tarkowska J., Pajączek A., Peszek Ł., Kochman-KęDziora N. \& Irlik E. 2015. Wykorzystanie okrzemek (Bacillariophyta) do oceny jakości wód rzeki Białej Tarnowskiej. Inżynieria Ekologiczna 42: 17-27. http://dx.doi.org/10.12912/23920629/1973

Novais M. H, Jüttner I., VAn de Vijver B., Morais M. M., Hoffmann L. \& Ector L. 2015. Morphological variability within the Achnanthidium minutissimum species complex (Bacillariophyta): comparison between the type material of Achnanthes minutissima and related taxa, and new freshwater Achnanthidium species from Portugal. Phytotaxa 224: 101-139.

Pajączek A., Musialek M., Pelczar J. \& Noga T. 2012. Diversity of diatoms Bacillariophyceae) in the Mleczka River, Morwawa River and Rożanka stream (tributaries of the Wisłok River, SE Poland), with particular reference to threatened species. In: K. WOŁOWSKI, I. Kaczmarska, J. M. Ehrman \& A. Z. Wojtal (eds.). Current advances in algal taxonomy and its applications: phylogenetic, ecological and applied perspective, pp. 129-151. W. Szafer Institute of Botany, Polish Academy of Sciences, Kraków.

PANEK P. 2011. Wskaźniki biotyczne stosowane w monitoringu wód od czasu implementacji w Polsce Ramowej Dyrektywy Wodnej. Przegląd Przyrodniczy 22(3): 111-123.

Peszek Ł., Noga T., Stanek-Tarkowska J., Pajączek A., Kochman-KęDziora N. \& PieniążeK M. 2015. The effect of anthropogenic change in the structure of diatoms and water quality of the Żołynianka and Jagielnia streams. Journal of Ecological Engineering 16(2): 33-51. http://dx.doi.org/10.12911/ 22998993/1856
Prygiel J. 2002. Mangement of the diatom monitoring network in France. J. App. Phycol. 14: 19-26. http:// dx.doi.org/10.1023/A:1015268225410

Prygiel J. \& Coste M. 1993. The assessment of water quality in the Artois-Picardie water basin (France) by the use of diatom indices. Hydrobiologia 269/270: 343-349. http://dx.doi.org/10.1007/BF00028033

Prygiel J., Whitton B. A. \& Bukowska J. (eds.). 1999. Use of the algae for monitoring rivers III. Agence de I'Eau Artis-Picardie.

RAIŃCZUK A. 2009. Uwarunkowania wynikające ze stanu i funkcjonowania środowiska przyrodniczego rzeźba terenu. Załącznik nr 68 do uchwały nr XXXVII/113/2000 Rady Miasta Rzeszowa z dnia 4 lipca 2000 r., Rzeszów.

RAKowska B. 2001. Studium różnorodności okrzemek ekosystemów wodnych Polski niżowej. 77 pp. Wyd. Uniw. Łódzkiego, Łódź.

Rakowska B. \& Szczepocka E. 2011. Demonstration of the Bzura River restoration using diatom indices. Biologia 66(3): 411-417. http://dx.doi.org/10.2478/ s11756-011-0032-3

Reichardt E. 1999. Taksonomy. Zur revission der Gattung Gomphonema. Die Arten um G. affine/insigne, G. angustum/micropus, G. acuminatum sowie gomphonemoide Diatomeen aus dem Oberoligozän in Böhmen In: H. LANGe-Bertalot (ed.). Iconographia Diatomologica. Annotated Diatom Mocrographs 8: 1-203. A. R. G. Gantner Verlag K.G., Ruggell.

Regulation 2011. Regulation of the Minister of Environment of 9 Nov 2011 on the way of classification of the condition of uniform parts of surface waters and environmental quality standards for priority substances. J. Laws 2011. No. 257, item 1545.

Round F. E. 1962. The application of diatom ecology to water pollution and purification. Biological problems in water pollution, pp. 29-33. Dep. Health Educ. and Welfare, Publ. Health Serv. Div. Water Suppl. Pollut. Control, Cincinnati, Ohio.

Siemińska J., BĄK M., Dziedzic J., GąBKa M., Gregorowicz P., Mrozińska T., Pelechaty M., Owsianny P. M., Pliński M. \& Witkowski A. 2006. Red list the algae in Poland. In: Z. MireK, K. Zarzycki, W. WojewodA \& Z. SZELĄG (eds.). Red list of plants and fungi in Poland, pp. 35-52. W. Szafer Institute of Botany, Polish Academy of Sciences, Kraków.

SŁysz K., Czerwieniec M., Schmager M., Wiatrak W., Zgud K. \& SZALIŃSKA E. 2004. Program ochrony środowiska z planem gospodarki odpadami miasta Rzeszowa, Rzeszów.

SzCzepocka E. \& Szulc B. 2009. The use of benthic diatoms in estimating water quality of variously polluted rivers. Oceanol. Hydrobiol. St. 38(1): 17-26. http://dx.doi. org/10.2478/v10009-009-0012-x

Szczepocka E, Szulc K., Szulc B. \& Żelazna-Wieczorek J. 2014. Diatom indices in the biological assessment of the water quality based on the example of a small lowland river. Oceanol. Hydrobiol. St. 43(3): 265-273. http://dx.doi.org/10.2478/s13545-014-0141-z

Szabó K., Kiss K.T., Ector L., Kecskés M. \& Ács E. 2004. Benthic diatom flora in a small Hungarian tributary 
of River Danube (Rákos-stream). Arch. Hydrobiol. Suppl. Algolog. St. 111: 79-94.

SzELĄG-WASIELEWSKA E. 2004. Dynamic of autotrophic picoplankton communities in the epilimnion of a eutrophic Lake (Strzeszyńskie Lake, Poland). Ann. Limnol. Int. J. Limn. 40(2): 13-120.

Śliwa-Dominiak J. \& DeptuŁa W. 2012. Przepisy dotyczące monitoringu wód powierzchniowych w Polsce. Ochrona Środowiska i zasobów naturalnych 54: 39-50.

TAmbor A. \& NogA T. 2011. Różnorodność flory okrzemek w rzece Lubcza i potoku Lubenia (Podgórze Rzeszowskie, Polska SE). Rocznik Przemyski 47(3): 105-118.

Ter Braak C.J.F. \& Šmilauer P. 2012. Canoco reference manual and user's guide. Software for ordination (version 5.0). Microcomputer Power, Ithaca, NY, USA. 496 pp.

Werum M. \& Lange-Bertalot H. 2004. Diatoms in springs from Central Europe and elsewhere dunder the influence of hydrogeology and antrophogenic impacts. 480 pp. A. R. G. Gantner Verlag K. G., Germany.

Whitton B. A., Rott E. \& Friendrich G. (eds.). 1991. Use of the algae for monitoring Rivers I. 193 pp. Institut für Botanik, Universität Insbruck.

Whitton B. A. \& Rott E. (eds.). 1996. Use of Algae for Monitoring Rivers 2. 196 pp. Institut für Botanic, Uniwersität Innsbruck.

WitaK M. 2013. Diatom biofacies in the SW Gulf of Gdańsk and the Vistula Lagoon (the southern Baltic Sea) as indicators of the basin evolution in the Middle and Late Holocene. Oceanol. Hydrobiol. St. 42(1): 70-88. http://dx.doi.org/10.2478/s13545-013-0052-4

WitKowski A., RadZIEJEWSKa T., WAWRZYNIAK-WydRowSKA B., Lange-Bertalot H., Bąk M. \& Gelbrecht J. 2011. Living on the $\mathrm{pH}$ Edge: Diatom Assemblages of Low - pH Lakes in Western Pomerania (NW Poland). Cellular Orgin, Life in Extreme Habitats and Astrobiology 19: 365-384. http://dx.doi.org/10.1007/978-94-0071327-7_16

Wojtal A. $20 \overline{1} 3$. Species composition and distribution of diatom assemblages in spring waters from various geological formations in southern Poland. Bibliotheca Diatomologica 59: 1-436.

Van Dam H., Martens A. \& Sinkeldam J. 1994. A coded checklist and ecological indicator values of freshwater diatoms from the Netherlands. Netherlands J. Aquatic Ecol. 28: 117-133. http://dx.doi.org/10.1007/ BF02334251

ŻELAZNA-WIECZOREK J. 2011. Diatom flora in springs of Łódź Hills (Central Poland). Biodiversity, taxonomy and temporal changes of epipsammic diatom assemblages in springs affected by human impact. Diatom Monographs 13: 1-420. A. R. G. Gantner Verlag K.G.

Żelazowski E., Magiera M., Kawecka B., Kwadrans J. \& Kотоwicz J. 2004. Use of algae for monitoring rivers in Poland - In the light of a new law for environmental protection. Oceanol. Hydrobiol. St. 33(4): 27-39.

Appendix 1. The list of diatom taxa recorded in the Przyrwa stream in 2011-2012 (dominant taxa are bolded)

\author{
Achnanthes coarctata (Brébisson) Grunow \\ Achnanthes expressa J.R.Carter \\ Achnanthidium eutrophilum (Lange-Bert.) Lange-Bert. \\ Achnanthidium minutissimum (Kütz.) Czarnecki \\ var. minutissimum \\ Achnanthidium pyrenaicum (Hust.) Kobayasi \\ Adlafia bryophila (Petersen) Lange-Bert. \\ Adlafia minuscula (Grunow) Lange-Bert. \\ var. minuscula \\ Amphora copulata (Kütz.) Schoeman \& Archibald \\ Amphora inariensis Krammer \\ Amphora indistincta Levkov \\ Amphora lange-bertalotii Levkov \& Metzeltin \\ Amphora lange-bertalotii var. tenuis \\ Levkov \& Metzeltin
}

\author{
Amphora ovalis (Kütz.) Kütz. \\ Amphora pediculus (Kütz.) Grunow \\ Anomoeneis sphaerophora Pfitzer \\ Brachysira calcicola ssp. pfisteri \\ Lange-Bert. \& Werum \\ Brachysira sp. \\ Caloneis amphisbaena (Bory) Cleve \\ Caloneis fontinalis (Grunow) Lange-Bert. \& Reichardt \\ Caloneis lancettula \\ (Schulz-Danzing) Lange-Bert. \& Witkowski \\ Caloneis macedonica Hust. \\ Caloneis molaris (Grunow) Krammer \\ Caloneis silicula (Ehrenb.) Cleve \\ Chamaepinnularia muscicola \\ (Petersen) Kulikovskiy, Lange-Bert. \& Witkowski
}


Chamaepinnularia submuscicola

(Krasske) Lange-Bert.

Cocconeis pediculus Ehrenb.

Cocconeis placentula var. euglypta (Ehrenb.) Grunow

Cocconeis placentula var. lineata

(Ehrenb.) Van Heurck

Craticula accomoda (Hust.) D.G. Mann

Craticula ambigua (Ehrenb.) D.G. Mann

Craticula cuspidata (Kütz.) D.G. Mann

Craticula molestiformis (Hust.) Lange-Bert.

Cyclotella meneghiniana Kütz.

Cymatopleura solea (Brébisson) W. Smith var. solea

Cymatopleura solea var. apiculata (W. Smith) Ralfs

Cymbella cymbiformis C. Agardh

Cymbella excisa Kütz.

Cymbella subcistula Krammer

Cymbopleura inaequaliformis Krammer

Cymbopleura inaequalis (Ehrenb.) Krammer

Cymbopleura subaequalis (Grunow) Krammer

var. subaequalis

Denticula subtilis Grunow

Denticula tenuis Kütz.

Diadesmis contenta (Grunow) D.G. Mann

Diadesmis paracontenta ssp. paracontenta

Lange-Bert. \& Werum

Diadesmis sp.

Diatoma vulgaris Bory

Diatoma cf. moniliformis (Kütz.) D.M. Williams

Diploneis fontanella Lange-Bert.

Diploneis krammeri Lange-Bert. \& Reichardt

Diploneis minuta Petersen

Diploneis oculata (Brébisson) Cleve

Diploneis separanda Lange-Bert.

Discostella pseudostelligera (Hust.) Houk \& Klee

Encyonema minutum (Hilse) D.G. Mann

Encyonema silesiacum (Bleisch) D.G. Mann

Encyonema ventricosum (C. Agardh) Grunow

Encyonopsis minuta Krammer \& Reichardt

Eolimna minima (Grunow) Lange-Bert.

Eolimna subminuscula

(Manguin) Moser, Lange-Bert. \& Metzeltin

Epithemia adnata (Kütz.) Brébisson

Epithemia sorex Kütz.

Eunotia bilunaris (Ehrenb.) Schaarschmidt

Eunotia botuliformis Wild, Nörpel \& Lange-Bert.

Eunotia valida Hust.

Eunotia sp.

Fallacia lenzii (Hust.) Lange-Bert.

Fallacia monoculata (Hust.) D.G. Mann

Fallacia pygmaea (Kütz.) A.I. Srickle \& D.G. Mann ssp.

pygmaea

Fallacia pygmaea ssp. subpygmaea

Lange-Bert., Cavacini, Tagliaventi \& Alfinito

Fallacia subhamulata (Grunow) D.G. Mann

Fistulifera saprophila

(Lange-Bert. \& Bonik) Lange-Bert.

Fragilaria capucina Desmazières var. capucina

Fragilaria gracilis Østrup

Fragilaria perminuta (Grunow) Lange-Bert.

Fragilaria radians (Kütz.) Lange-Bert.

Fragilaria recapitellata Lange-Bert. \& Metzeltin

Fragilaria rumpers (Kütz.) Carlson

Fragilaria vaucheriae (Kütz.) Petersen

Frustulia saxonica Rabenh.

Frustulia vulgaris (Thwaites) De Toni

Gomphonema acidoclinatum Lange-Bert. \& Reichardt

Gomphonema acuminatum Ehrenb. var. acuminatum

Gomphonema capitatum Ehrenb.

Gomphonema clavatum Ehrenb.

Gomphonema drutelingense Reichardt

Gomphonema exillisimum

(Grunow) Lange-Bert. \& Reichardt

Gomphonema gracile Ehrenb.
Gomphonema insigne Gregory

Gomphonema italicum Kütz.

Gomphonema micropus Kütz.

Gomphonema minutum (C. Agardh) C. Agardh

Gomphonema olivaceum (Hornemann) Brébisson

var. olivaceum

Gomphonema pala Reichardt

Gomphonema parvulius

(Lange-Bert. \& Reichardt) Lange-Bert. \& Reichardt

Gomphonema parvulum (Kütz.) var. parvulum

Gomphonema parvulum Lange-Bert. \& Reichardt

var. parvulum f. saprophilum

Gomphonema pumilum

(Grunow) Reichardt \& Lange-Bert.

Gomphonema sarcophagus Gregory

Gomphonema subclavatum (Grunow) Grunow

Gomphonema utae Lange-Bert. \& Reichardt

Gomphonema cf. bohemicum Reichelt \& Fricke

Gomphonema cf. pumilum

(Grunow) Reichardt \& Lange-Bert.

Gomphonema cf. sarcophagus Gregory

Gomphonema sp. 1

Gomphonema sp. 2

Gomphonema sp. 3

Gomphonema sp. 4

Gyrosigma acuminatum (Kütz.) Rabenh.

Gyrosigma attenuatum (Kütz.) Rabenh.

Gyrosigma obtusatum

(Sullivant \& Wormley) C.S. Boyer

Halamphora montana (Krasske) Levkov

Halamphora normannii (Rabenh.) Levkov

Hantzschia abundans Lange-Bert.

Hantzschia amphioxys (Ehrenb.) Grunow

Hantzschia calcifuga Reichardt \& Lange-Bert.

Hippodonta capitata

(Ehrenb.) Lange-Bert., Metzeltin \& Witkowski

Lemnicola hungarica (Grunow) Round \& Basson

Luticola acidoclinata Lange-Bert.

Luticola dismutica (Hust.) D.G. Mann

Luticola goeppertiana (Bleisch) D.G. Mann

Luticola mutica (Kütz.) D.G. Mann

Luticola nivalis (Ehrenb.) D.G. Mann

Luticola ventriconfusa Lange-Bert.

Luticola ventricosa (Kütz.) D.G. Mann

Luticola cf. dismutica (Hust.) D.G. Mann

Luticola sp.

Mayamaea atomus (Kütz.) Lange-Bert. var. atomus

Mayamaea atomus var. permitis (Hust.) Lange-Bert.

Mayamaea asellus (Weinhold) Lange-Bert.

Mayamaea excelsa (Krasske) Lange-Bert.

Mayamaea fossalis (Krasske) Lange-Bert.

var. fossalis.

Mayamaea cf. agrestis (Hust.) Lange-Bert.

Melosira varians $\mathbf{C}$. Agardh

Meridion circulare (Grèville) C. Agardh

var. circulare

Meridion circulare var. constrictum

(Ralfs) Van Heurck

Navicula antonii Lange-Bert.

Navicula aquaedurae Lange-Bert.

Navicula capitatoradiata Germain

Navicula cari Ehrenb.

Navicula cariocincta Lange-Bert.

Navicula cincta (Ehrenb.) Ralfs

Navicula cryptocephala Kütz.

Navicula cryptonella Lange-Bert.

Navicula erifuga Lange-Bert.

Navicula gregaria Donkin

Navicula kotschyi Grunow

Navicula lacuum

Lange-Bert., G. Hofmann, Werum \& Van de Vijver

Navicula lanceolata (C. Agardh) Ehrenb.

Navicula libonensis Schoeman 
Navicula lundii Reichardt

Navicula radiosa Kütz.

Navicula reichardtiana Lange-Bert.

Navicula slesvicensis Grunow

Navicula tenelloides Hust.

Navicula tripunctata (O.F. Müller) Bory

Navicula trivialis Lange-Bert.

Navicula vandamii Schoeman \& Archibald

var. vandamii

Navicula veneta Kütz.

Navicula vilaplanii

(Lange-Bert. \& Sabater) Lange-Bert. \& Sabater

Navicula viridula (Kütz.) Ehrenb.

Navicula wiesnerii Pantocsek

Navicula wildii Lange-Bert.

Neidium ampliatum (Ehrenb.) Krammer

Neidium binodeforme Krammer

Neidium cf. affine (Ehrenb.) Pfitzen

Nitzschia acicularis (Kütz.) W. Smith

Nitzschia acidoclinata Lange-Bert.

Nitzschia adamata Hust.

Nitzschia amphibia Grunow

Nitzschia archibaldii Lange-Bert.

Nitzschia calida Grunow

Nitzschia capitellata Hust.

Nitzschia communis Rabenh.

Nitzschia constricta (Kütz.) Ralfs

Nitzschia debilis (Arnott) Grunow

Nitzschia desertorum Hust.

Nitzschia dissipata (Kütz.) Grunow ssp. dissipata

Nitzschia dissipata var. media (Hantzsch) Grunow

Nitzschia dubia W. Smith

Nitzschia frustulum (Kütz.) Grunow var. frustulum

Nitzschia gracilis Hantzsch

Nitzschia hantzschiana Rabenh.

Nitzschia heufleriana Grunow

Nitzschia hungarica Grunow

Nitzschia intermedia Hantzsch

Nitzschia linearis (C. Agardh) W. Smith

Nitzschia palea var. debilis (Kütz.) Grunow

Nitzschia palea (Kütz.) W. Smith var. palea

Nitzschia paleacea (Grunow) Grunow

Nitzschia perminuta (Grunow) M. Peragallo

Nitzschia pusilla Grunow

Nitzschia recta Hantzsch

Nitzschia sigma (Kütz.) W. Smith

Nitzschia sigmoidea (Nitzsch) W. Smith

Nitzschia solgensis Cleve-Euler

Nitzschia sublinearis (?) Hust.

Nitzschia subtilis Grunow

Nitzschia supralitorea Lange-Bert.

Nitzschia tenuis W. Smith

Nitzschia tubicola Grunow

Nitzschia umbonata (Ehrenb.) Lange-Bert.

Nitzschia vermicularis (Kütz.) Hantzsch

Nitzschia cf. ovalis Arnott

Nitzschia sp.

Pinnularia appendiculata (C. Agardh) Cleve

Pinnularia borealis Ehrenb. var. borealis

Pinnularia borealis var. sublinearis Krammer
Pinnularia brebissonii (Kütz.) Rabenh.

Pinnularia kuetzingii Krammer

Pinnularia neomajor Krammer

Pinnularia obscura Krasske

Pinnularia subrupestris Krammer var. subrupestris

Pinnularia viridiformis Krammer

Pinnularia sp. cf. kuetzingii Krammer

Placoneis paraelginensis Lange-Bert.

Planothidium bipromum

(Hohn \& Hellerman) Lange-Bert.

Planothidium frequentissimum

(Lange-Bert.) Lange-Bert.

Planothidium rostratum (Østrup) Lange-Bert.

Planothidium lanceolatum (Brébisson) Lange-Bert.

Platessa conspicua (A. Mayer) Lange-Bert.

Platessa holsatica (Hust.) Lange-Bert.

Psammothidium bioretii

(Germain) Bukhtiyarova \& Round

Psammothidium lauenburgianum

(Hust.) Bukhtiyarova \& Round

Reimeria sinuata (Gregory) Kociolek \& Stoermer

Rhoicosphenia abbreviata (C. Agardh) Lange-Bert.

Rhopalodia gibba (Ehrenb.) O. Müller var. gibba

Sellaphora joubaudii (Germain) Aboal

Sellaphora bacilloides

(Hust.) Levkov, Krstic \& Nakov

Sellaphora pseudopupula (Krasske) Lange-Bert.

Sellaphora pupula (Kütz.) Mereschowsky

Sellaphora seminulum (Grunow) D.G. Mann

Sellaphora cf. pseudopupula (Krasske) Lange-Bert.

Simonsenia delognei (Grunow) Lange-Bert.

Stauroneis anceps Ehrenb.

Stauroneis gracilis Ehrenb.

Stauroneis leguminopsis Lange-Bert. \& Krammer

Stauroneis parathermicola Lange-Bert.

Stauroneis phoenicenteron (Nitzsch) Ehrenb.

Stauroneis reichardtii Lange-Bert.

Stauroneis separanda Lange-Bert. \& Werum

Stauroneis smithii Grunow

Stauroneis tackei

(Hust.) Krammer, Lange-Bert., Kusber \& Metzeltin

Stauroneis termicola (Petersen) Lund

Surirella angusta Kütz.

Surirella brebissonii Krammer \& Lange-Bert.

var. brebissonii

Surirella brebissonii var. kuetzingii

Krammer \& Lange-Bert.

Surirella helvetica Brun

Surirella linearis W. Smith

Surirella minuta Brébisson

Surirella ovalis Brébisson

Surirella tenera Gregory

Surirella terricola Lange-Bert.

Tabularia fasciculata

(C. Agardh) D.M. Williams \& Round

Ulnaria acus (Kütz.) Aboal

Ulnaria biceps (Kütz.) Compère

Ulnaria oxyrhynchus (Kütz.) Aboal

Ulnaria ulna (Nitzsch) Compère 